\title{
Studies on digestion and absorption in the intestines of growing pigs. Measurements of the flow of digesta and $\mathrm{pH}$
}

\author{
By R. BRAUDE, ROSEMARY J. FULFORD AND A. G. LOW \\ National Institute for Research in Dairying, \\ Shinfield, Reading RG2 $9 A T$, Berks.
}

(Received 6 February 1976 - Accepted I5 March 1976)

\begin{abstract}
I. Thirty-five pigs were fitted with single re-entrant cannulas in either the duodenum, jejunum or ileum. A further twenty-four pigs were used in a conventional digestibility trial.

2. Methods for collecting, sampling and returning digesta were developed.

3. A 'practical-type' diet and two purified diets were used, fed twice daily.

4. Flow and $\mathrm{pH}$ of digesta were measured hourly in the duodenum and jejunum, and every $6 \mathrm{~h}$ in the ileum.

5. In the duodenum and jejunum there were clear flow responses to feeding, while such an effect was not found in the ileum where the flow-rate was much lower and more uniform than in the former sites.

6. In the duodenum and jejunum, and within $6 \mathrm{~h}$ periods in the ileum, there was considerable variation in the flow-rate between different pigs within each hour but there was less variation in $\mathrm{pH}$.

7. The pattern of flow in the duodenum and jejunum was similar for each of the diets but the total flow and the average $\mathrm{pH}$ in $24 \mathrm{~h}$ differed significantly between diets. There were more digesta of a lower $\mathrm{pH}$ from the 'practical-type' diet than the purified diets.

8. The $\mathrm{pH}$ in the duodenum was highest after feeding and decreased with increasing time after feeding. In the jejunum and ileum the $\mathrm{pH}$ varied over a much smaller range than in the duodenum.

g. Collections for $6 \mathrm{~h}$ periods appeared to be insufficiently long to predict the values obtained in $24 \mathrm{~h}$ collections with reasonable accuracy.
\end{abstract}

Interest in improving the utilization of feeding-stuffs by farm livestock has led to a wide range of studies on the function of the gut, particularly in ruminants and, in recent years, in pigs, using animals surgically fitted with simple or re-entrant cannulas. The methods used in such work on simple-stomached species have been reviewed by Laplace (1972) and the results of trials with pigs have been discussed by Low (1974, 1976).

The re-entrant cannula method was used to study the general characteristics of the digestion of a variety of diets in the intestines of growing pigs. Particular attention was paid to developing methods of surgery, housing and digesta collection. A sufficient number of animals was used to assess the variability of the processes. An estimate of the extent of digestion and absorption in the large intestine was made by comparing results from pigs with re-entrant cannulas sited in the terminal ileum with results from pigs without cannulas participating in a conventional digestibility trial. This paper describes the flow of digesta and their $\mathrm{pH}$; studies on the contents of dry matter, ash, water, nitrogen, amino acids and enzymes in the same digesta will be described in subsequent papers. 


\section{METHODS \\ Experimental procedures}

Animals and housing. Castrated male pigs from the Large White herd of the National Institute for Research in Dairying were used. The initial live weight of pigs fitted with re-entrant cannulas was $30 \mathrm{~kg}$, and for those without cannulas was $17-19 \mathrm{~kg}$. The pigs were housed at $18 \pm 3^{\circ}$. The cannulated pigs were kept in modified Shinfield metabolism cages (Plate $\mathrm{I}$ ) based on the design of Braude $\&$ Mitchell (1964). The modified cages measured I.35 $\times \mathrm{I} \cdot 35 \times 0.60 \mathrm{~m}$ and were made from $25 \mathrm{~mm}$ o.d. galvanized tubing. Two Perspex sheets were attached to the framework adjacent to the right-hand side of the pig: these sheets could be opened to allow free access to the cannulas. The floor sections were made of fine mesh stainlesssteel. The pigs in the digestibility trial were kept in standard Shinfield metabolism cages (Braude \& Mitchell, 1964).

Diets. Batches of diets BWF, SSG and SSC (for details, see Table I) contained $(\mathrm{g} / \mathrm{kg})$ respectively: dry matter $868.2,925^{\circ 2}$ and $91 \mathrm{I} \cdot 8$; ash $53^{\circ} \mathrm{I}, 52 \cdot 0$ and $34^{\circ} \mathrm{O}$; $\mathrm{N} \mathrm{22} \cdot 8,24 \cdot 7$ and $25 \cdot 6$. Because of frequent blockages of ileal re-entrant cannulas after feeding the normally-milled diet BWF, this diet was milled to pass through a $\mathrm{I} \mathrm{mm}$ mesh to give a finely-milled diet (diet $\mathrm{BWF}_{\mathrm{f}}$ ). Diet SSG contained free lysine and methionine (the diet was originally formulated for studies of amino acid requirements). The dry diet was mixed with water $(1: 2 \cdot 5, \mathrm{w} / \mathrm{w})$ and offered twice daily at 09.00 and 15.00 hours. The animals were weighed weekly and fed on a scale based on their live weight (Barber, Braude, Mitchell \& Pittman, 1972).

Cannulas. Polyvinyl chloride (PVC) re-entrant cannulas (Ash, r962) of $9 \mathrm{~mm}$ i.d. (for duodenum and jejunum) and ${ }_{5} \mathrm{~mm}$ i.d. (for ileum) were used. Certain batches of PVC paste resulted in soft cannulas: in these instances the gutters of the cannulas were strengthened with $0.5 \mathrm{~mm}$ thick stainless-steel plates, and these were very effective in preventing loss of cannulas during collections. The cannulas were connected externally with a slightly curved $30 \mathrm{~mm}$ length of stainless-steel tubing (wall thickness I mm) which fitted inside the barrel and which was securely fixed to the cannulas by two clips (Collier $062 \mathrm{P}$ or $087 \mathrm{P}$; Collier and Collier Ltd, 2-6 Marian $\mathrm{Rd}$, London SWI6 $5 \mathrm{JW}$ ). Some pigs were fitted with cannulas with gutters strengthened by immersion in light petroleum (b.p. $40-60^{\circ}$ ); these cannulas were rarely lost during collections.

Surgical procedures. Pigs were kept continuously in metabolism cages on diet BWF for at least $7 \mathrm{~d}$ before surgery. An antibiotic preparation was given with the feed during the last $3 \mathrm{~d}$ before surgery (Stromez; ICI Ltd, Pharmaceuticals Division, Alderley Park, Macclesfield, Cheshire) in order to reduce the possibility of enteric infection developing. On the day of surgery, pigs were given water only. Anaesthesia was induced with cyclopropane and oxygen through a cuffed endotracheal tube (McGill no. 8 or 9) from a closed-circuit Boyle apparatus. The gut was exposed through an incision $c .250 \mathrm{~mm}$ from the xiphisternum to the prepuce. The method of Markowitz, Archibald \& Downie (1954) was used for the rest of the surgical procedure, except that the jejunum cannulation site was found by following a $2.50 \mathrm{~m}$ 


\section{Table 1. Composition of experimental diets ( $\mathrm{g} / \mathrm{kg}$ diet)}

\begin{tabular}{|c|c|c|c|c|}
\hline Ingredients & $\begin{array}{c}\text { Diets } \\
\mathrm{BWF} \text { and } \\
\mathrm{BWF}_{\mathrm{f}}^{*}\end{array}$ & Ingredients & Diet SSG & Diet SSC \\
\hline Barley meal & $7 \times 2 \cdot 5$ & Maize starch & $277^{\circ} 0$ & $612 \cdot 7$ \\
\hline Fine wheat offal & $200 \cdot 0$ & Sucrose & $276 \cdot 9$ & 100.0 \\
\hline White fish meal & 70.0 & Maize oil & $30 \cdot 0$ & $30 \cdot 0$ \\
\hline $\mathrm{NaCl}$ & $2 \cdot 7$ & Solka Floc & 20.0 & $30 \cdot 0$ \\
\hline $\mathrm{CaHPO}_{4} \cdot 2 \mathrm{H}_{2} \mathrm{O}$ & $5 \cdot 6$ & Groundnut meal & $350 \cdot 0$ & - \\
\hline $\mathrm{CaCO}_{3}$ & $6 \cdot 2$ & Casein & - & 184.0 \\
\hline Vitamin mix no. i $\uparrow$ & $2 \cdot 0$ & Trace mineral mix & 10.0 & 10.0 \\
\hline \multirow[t]{7}{*}{$\mathrm{CuSO}_{4} \cdot 5 \mathrm{H}_{2} \mathrm{O}$} & $1 \cdot 0$ & $\mathrm{CaHPO}_{4} \cdot 2 \mathrm{H}_{2} \mathrm{O}$ & $17 \cdot 9$ & $20 \cdot 6$ \\
\hline & & $\mathrm{CaCO}_{3}$ & $4 \cdot 6$ & $4 \cdot 6$ \\
\hline & & Vitamin mix no. $2 \S$ & $2 \cdot 0$ & 2.0 \\
\hline & & Choline $\mathrm{HCl}$ & $I \cdot I$ & $\mathbf{r} \cdot \mathbf{I}$ \\
\hline & & $\mathrm{NaCl}$ & $5 \cdot 0$ & $5 \cdot 0$ \\
\hline & & $\mathrm{L}$-lysine $\mathrm{HCl}$ & $2 \cdot 5$ & - \\
\hline & & DL-methionine $\mathrm{HCl}$ & $3 \cdot 0$ & - \\
\hline
\end{tabular}

* Diet BWF after milling through a $1 \mathrm{~mm}$ mesh; this diet was given to pigs with ileal re-entrant cannulas, and to some pigs in the digestibility trial.

† Supplied (/kg diet) : $0.75 \mathrm{mg}$ retinol, $7.50 \mu \mathrm{g}$ cholecalciferol, $3.25 \mathrm{mg}$ riboflavin, $30.00 \mu \mathrm{g}$ cyanocobalamin, $15.75 \mathrm{mg}$ nicotinic acid, $13.00 \mathrm{mg}$ pantothenic acid, $3.25 \mathrm{mg}$ pyridoxine, $200.00 \mathrm{mg}$ choline chloride, $2.00 \mathrm{mg} \mathrm{DL}-\alpha$-tocopheryl acetate.

$\ddagger$ Supplied (/kg diet) : $4.47 \mathrm{~g} \mathrm{~K}_{2} \mathrm{CO}_{3}, \mathrm{I} \cdot 73 \mathrm{~g} \mathrm{MgCO} . \mathrm{H}_{2} \mathrm{O}, 0.33 \mathrm{~g} \mathrm{FeSO} / 7 \mathrm{H}_{2} \mathrm{O}, 60 \mathrm{mg} \mathrm{MnSO}$. $\mathrm{H}_{2} \mathrm{O}$, $0.10 \mathrm{~g} \mathrm{ZnCO}_{3}, 8.00 \mathrm{mg} \mathrm{NaF}, 17.50 \mathrm{mg} \mathrm{CuSO} 4.5 \mathrm{H}_{2} \mathrm{O}, 6.00 \mathrm{mg} \mathrm{CoCl}$.

$\S$ Supplied (/kg diet): as vitamin mix no. I (omitting choline chloride) and in addition $2.00 \mathrm{mg}$ thiamin, $50.00 \mu \mathrm{g}$ biotin, $0.50 \mathrm{mg}$ pteroylmonoglutamic acid, $20.00 \mathrm{mg} p$-aminobenzoic acid, $195.00 \mathrm{mg}$ myo-inositol, $30.00 \mathrm{mg}$ ascorbic acid, $2.00 \mathrm{mg}$ menaphthone.

length of thread as carefully as possible from the pylorus along the outside wall of the intestine.

Water alone was given to the animals for $36 \mathrm{~h}$ after surgery. From then feed was given in amounts which increased, according to appetite, up to the normal level, which was usually reached in $5-7 \mathrm{~d}$. Stromez was given daily for $5 \mathrm{~d}$ after surgery. The cannulas were checked twice daily for freedom from blockage. The cannulas and the surrounding skin were washed daily with Cetavlon (ICI Ltd).

Collection procedures. Digesta were collected from about $14 \mathrm{~d}$ after surgery, provided that the pig ate its feed within $20 \mathrm{~min}$. PVC tubing (Silastic; Dow Corning Ltd, obtained from Lepetit Pharmaceuticals, Heath Row House, Bath Road, Hounslow, Middlesex) was used to connect the cannulas to a sealed 'collection-and-return' system made in the workshop at this Institute (Fig. 1). Digesta were collected in a 11 PVC bottle surrounded by an ice-water mixture to minimize digestion after collection from the pig. The bottle was replaced every hour (or more frequently if the flow-rate was high) during collection from the duodenum and jejunum, and every $6 \mathrm{~h}$ during ileal collection because of the low rate of flow at this site. After sampling, the digesta were poured into the heated return vessel. As digesta passed into the collection bottle, digesta were returned to the pig at approximately the same rate, temperature and pressure. At the beginning of a collection, digesta collected after feeding on the previous day were used to prime the system. Between 5 and $10 \%$ of the digesta (depending on the size of the pig) were retained for 


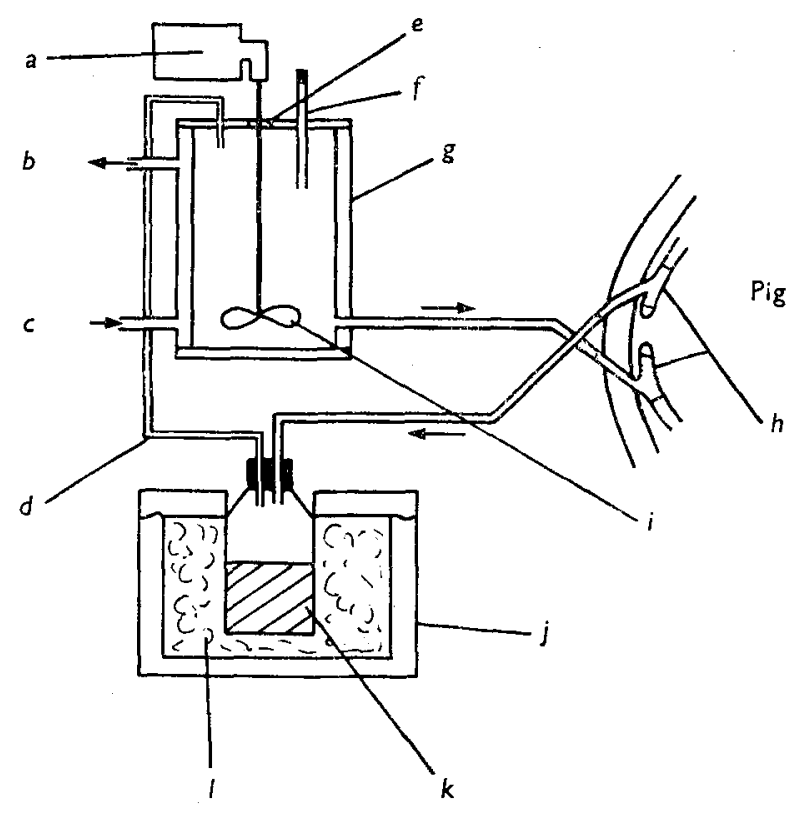

Fig. I. System used for collection and return of digesta in pigs with re-entrant cannulas. For details of procedures, see p. 499. $a$, Stirrer motor; $b$, water outlet; $c$, water input at $39^{\circ}$; $d$, air line; $e$, sealed bearing; $f$, tube for return of digesta; $g$, sealed return vessel; $h$, reentrant Ash cannulas; $i$, stirrer paddle; $j$, insulated container; $k$, sealed collection vessel; $l$, ice-water mixture.

analysis. Donor animals were not used to make up this deficit because of the large differences between individuals in the composition of digesta flowing at any given time. The digesta were weighed to the nearest gram and then stirred vigorously while samples were taken on a weight basis, using to or $25 \mathrm{ml}$ pipettes with tips cut to provide an aperture of about $4 \mathrm{~mm}$ diameter.

pH measurement. $\mathrm{pH}$ was measured with a Model $7^{8} \mathrm{pH}$ meter (W. \& G. Pye Ltd, Cambridge).

\section{Experimental design}

I. Cannulated pigs. It was originally intended to collect digesta from eighteen pigs, in three groups of six pigs, with a single re-entrant cannula in: $(a)$ the duodenum, about $150 \mathrm{~mm}$ from the pylorus and posterior to the bile and pancreatic ducts, (b) the jejunum, $2 \cdot 0-2 \cdot 5 \mathrm{~m}$ from the pylorus, i.e. $13-17 \%$ of the total length of the small intestine, or $(c)$ the ileum, $300 \mathrm{~mm}$ from the ileo-caecal junction, i.e. over $98 \%$ of the total length of the small intestine.

The first six pigs with duodenal cannulas only received diet BWF and diet SSG. However, experience with these pigs suggested that the pigs were in sufficiently good condition after all planned collections to introduce a third diet (diet SSC). For this reason, and in order to provide samples for a more detailed study of the digesta than possible at the outset of the work, it was planned to collect digesta from a second set of six pigs with duodenal re-entrant cannulas given all three diets.

For pigs with duodenal and jejunal cannulas, six collections per diet were planned; four collections of $6 \mathrm{~h}$, from 09.00 to 15.00 hours, and two collections of $24 \mathrm{~h}$, 
starting at 09.00 hours. For pigs with ileal re-entrant cannulas four $24 \mathrm{~h}$ collections per diet were planned. Each diet was fed to each pig for approximately 2 weeks, including a $5 \mathrm{~d}$ changeover period between diets.

2. Digestibility trial in pigs without cannulas. Six replicates of four litter-mate pigs, which were randomly assigned to the four diets, were used. Each pig received the same diet throughout the trial. The pigs were kept in a metabolism cage for four $7 \mathrm{~d}$ periods evenly spaced through the growing period $(20-60 \mathrm{~kg}$ live weight): the periods began immediately after the weekly weighing, and the first $2 \mathrm{~d}$ were for adaptation to the higher level of feeding and to the cage. Faeces and urine were collected daily for the next $5 \mathrm{~d}$.

\section{Method of presentation of results}

$\mathrm{pH}$ is given as a direct measurement and amounts of digesta or faeces as the ratio, weight collected in a specified time: weight of feed and water consumed in $24 \mathrm{~h}$ (output: intake).

The hourly mean values for digesta flow and $\mathrm{pH}$ values for each hour within the $24 \mathrm{~h}$ collection periods (for pigs with duodenal or jejunal cannulas) were calculated from the average values for all $24 \mathrm{~h}$ collection periods completed by each pig on a diet, and are shown as a histogram or graph. The mean values for pigs with ileal cannulas are for $6 \mathrm{~h}$ periods. The areas of the histograms in Fig. 2 are in proportion to the amounts of digesta at all sites.

The mean value for output:intake of digesta in $24 \mathrm{~h}$ collection periods was calculated from the average values for the $24 \mathrm{~h}$ collections for each pig on a diet. The mean values for the digestibility trial were based on the average values for the four collection periods for each pig. These are given in tables of determined mean values and standard deviations (Tables 3 and 5). In several instances these means differ slightly from those given in the statistical analysis where missing values were estimated and incorporated in the means. Details of the statistical analysis are given in Tables 2 and 4 . The comparison between ileal digesta and faeces has been included to indicate the role of the large intestine.

\section{RESULTS}

\section{Pigs fitted with cannulas}

In the course of this study thirty-five pigs were fitted with re-entrant cannulas in the duodenum (seventeen), jejunum (eight) or ileum (ten). Results are given for twelve, five and six pigs at the three sites respectively, which completed collections on two or three diets, and for twenty-four pigs used in the digestibility trial.

The average daily gain of the cannulated pigs was $505 \mathrm{~g}$ during the collection periods.

Thirteen of the twenty-three cannulated pigs completed all planned collections. Collections ended prematurely on the remaining ten pigs for the following reasons: cannulas pulled out (four), leakage of digesta from around the cannulas (four), rupture of the intestinal wall caused by a displaced cannula (one) and rectal prolapse (one). Of the other twelve pigs, one pig completed collections on one diet only 
and then had a jejunal prolapse, while the others died shortly after surgery as a result of rupture of the intestinal wall, twisted intestine or unspecified infection.

The fact that only two pigs with ileal cannulas completed collections on diet SSG because of palatability problems and scouring must be noted in all comparisons for this diet at this site.

\section{Length of digesta collections}

At the outset of this study it was considered possible that the flow of digesta and their constituents during $6 \mathrm{~h}$ collections (between morning and afternoon feeds) might form a constant proportion of the flow in $24 \mathrm{~h}$ collection periods. It was found that some between-diet and between-site differences were statistically significant for $6 \mathrm{~h}$ collections but not for $24 \mathrm{~h}$ collections. It was concluded that while $6 \mathrm{~h}$ collections were insufficiently long to predict $24 \mathrm{~h}$ values reliably, further analysis of the results for other intermediate periods was merited and this will be published later.

\section{Digesta flow}

The mean hourly flow of digesta (output:intake) is shown in Fig. 2.

The highest flow-rates in both the duodenum and jejunum occurred after feeding, for all diets; it was also found that there was some flow in each hour of a $24 \mathrm{~h}$ collection period. The effect of feeding was only evident in the ileum to the extent that the lowest flow-rates were usually found $12-18 \mathrm{~h}$ after the afternoon feed. The flow patterns in the duodenum and jejunum were similar for each diet. Within any hour in the duodenum and jejunum (or within any $6 \mathrm{~h}$ period in the ileum) the variation between pigs on each diet was large. The corresponding coefficients of variation (\%) between pigs were, on average, duodenum 50 , jejunum 43 , ileum 31 .

The $24 \mathrm{~h}$ output:intake values for digesta are given in Tables 2 and 3 . In almost all instances there was significantly more digesta or faeces from diet BWF than the other diets, and there was less from diet SSC than the other diets. It is notable that there was a smaller amount of faeces with the finely-milled diet $\mathrm{BWF}_{\mathrm{f}}$ than its normally-milled counterpart; particular caution must therefore be taken over comparisons between the ileum and other sites for digesta from this diet.

$$
\text { 4. } p H
$$

The pattern of hourly $\mathrm{pH}$ changes is shown in Fig. 3 , and the $24 \mathrm{~h}$ mean $\mathrm{pH}$ values are given in Tables 4 and 5 .

It was found that the $\mathrm{pH}$ in the duodenum was highest $2-3 \mathrm{~h}$ after feeding, and that the $\mathrm{pH}$ decreased at night, at times when digesta flow was lower (Fig. 2). The periods when $\mathrm{pH}$ was high were longer than the periods of high digesta flow. At other times there were signs that when flow increased, the $\mathrm{pH}$ decreased; periods of high flow-rate were also periods when there was high dry-matter flow (A. G. Low, I. G. Patridge \& I. E. Sambrook, unpublished results) and therefore periods of high gastric emptying when hydrochloric acid would be an important component of the digesta. At times of low flow the digesta had a low dry-matter content and appeared to be largely composed of bile and pancreatic juice (enzyme activities were high 


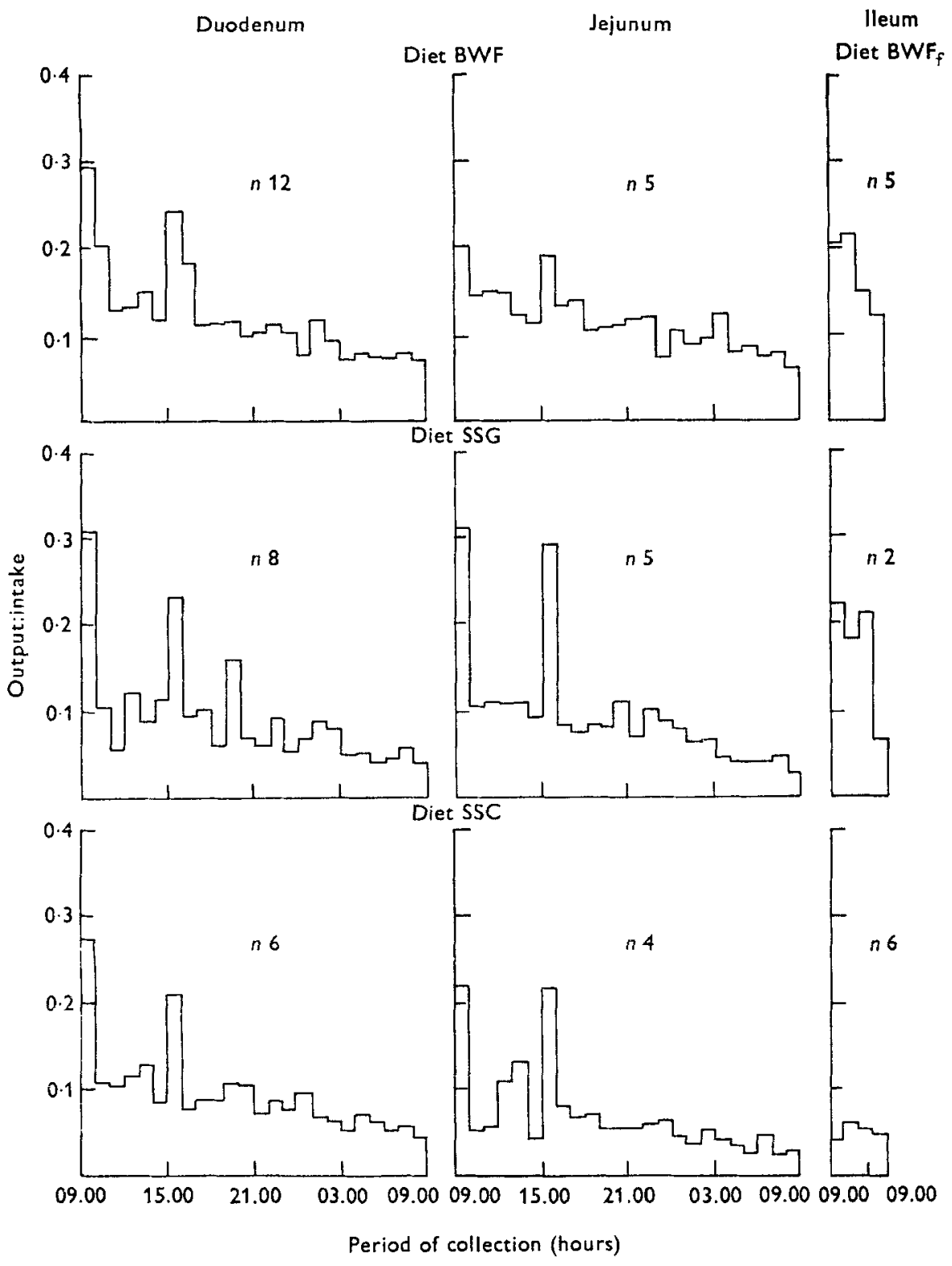

Fig. 2. Mean hourly flow (6 h flow in ileum) of digesta (digesta output: feed and water intake (output:intake)) in pigs each fitted with a re-entrant cannula at one of three sites (for details, see p. 500) and given successively diets BWF (or BWF $)$, SSG and SSC (for details, see Table $\mathrm{I}$ ). Pigs were fed at 09.00 and 15.00 hours; $n$ is the no. of pigs completing collections.

under such conditions); these secretions are of $\mathrm{pH} 7 \cdot 0-7 \cdot 5$. The fact that the $\mathrm{pH}$ rarely reached these values indicated that gastric secretions were usually present in the digesta. The $\mathrm{pH}$ values for the diets, as fed, were $6.1,7.5$ and 7.7 for diets $\mathrm{BWF}$, SSG and SSC respectively. The $\mathrm{pH}$ of the water was $7 \cdot 6$. As with digesta flow, 
504

R. Braude, Rosemary J. Fulford and A. G. Low

r976

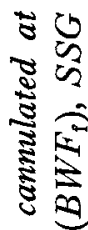

.

$\rightarrow$

:

离

$\underset{30}{30}$

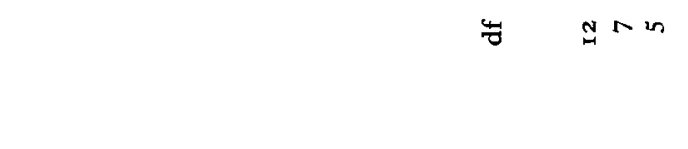

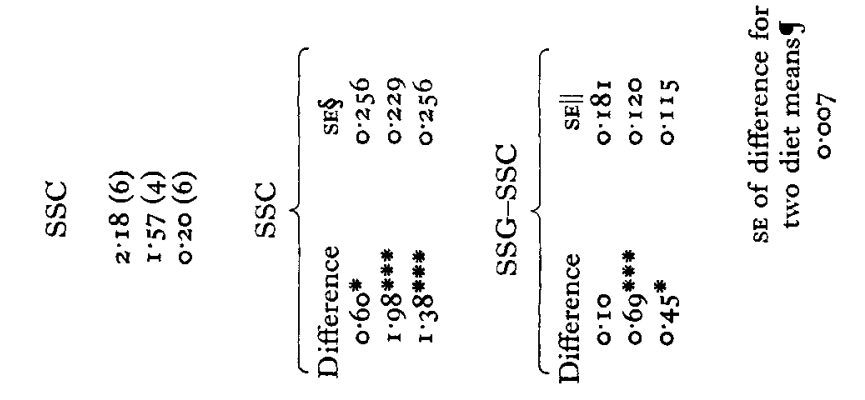

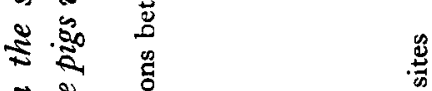

.$\Sigma$

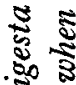

क्ष

के है

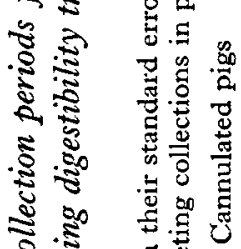

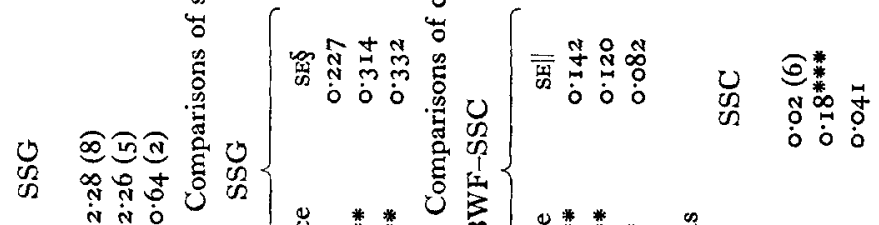

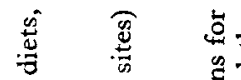

政

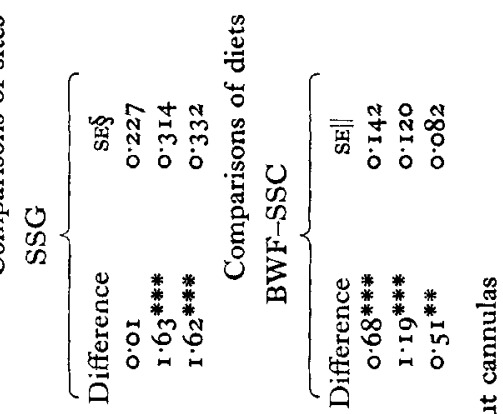

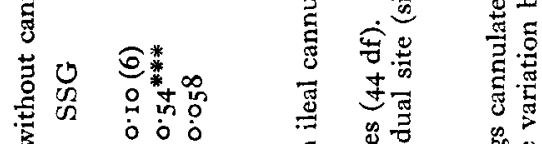

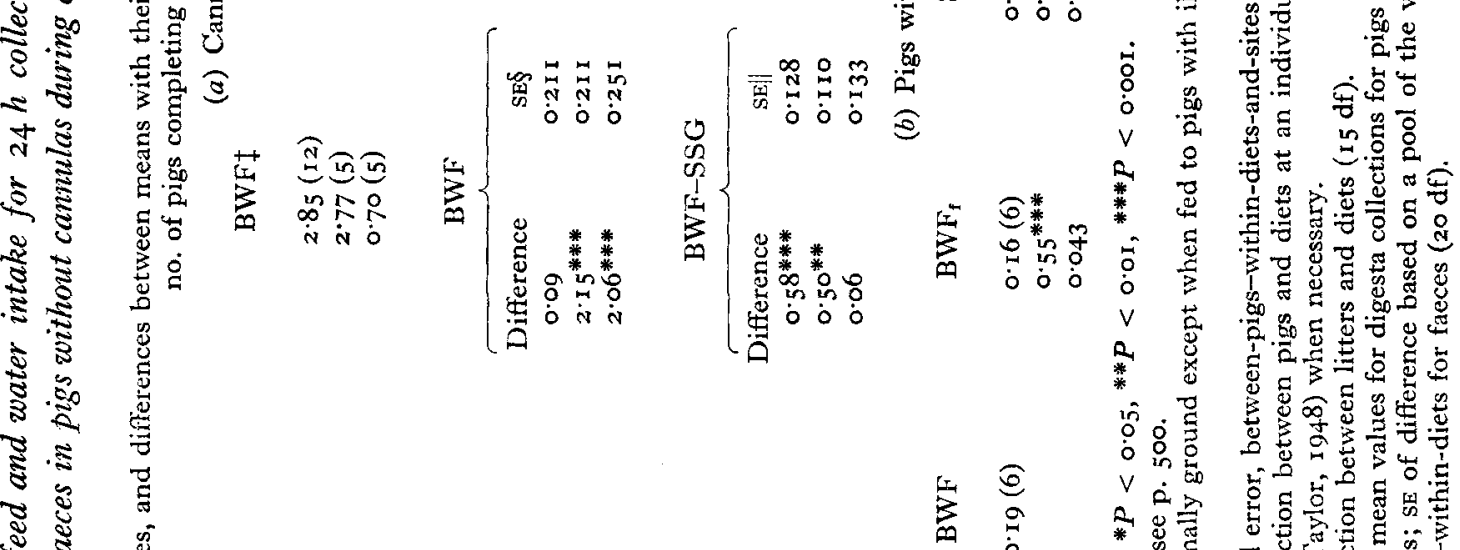

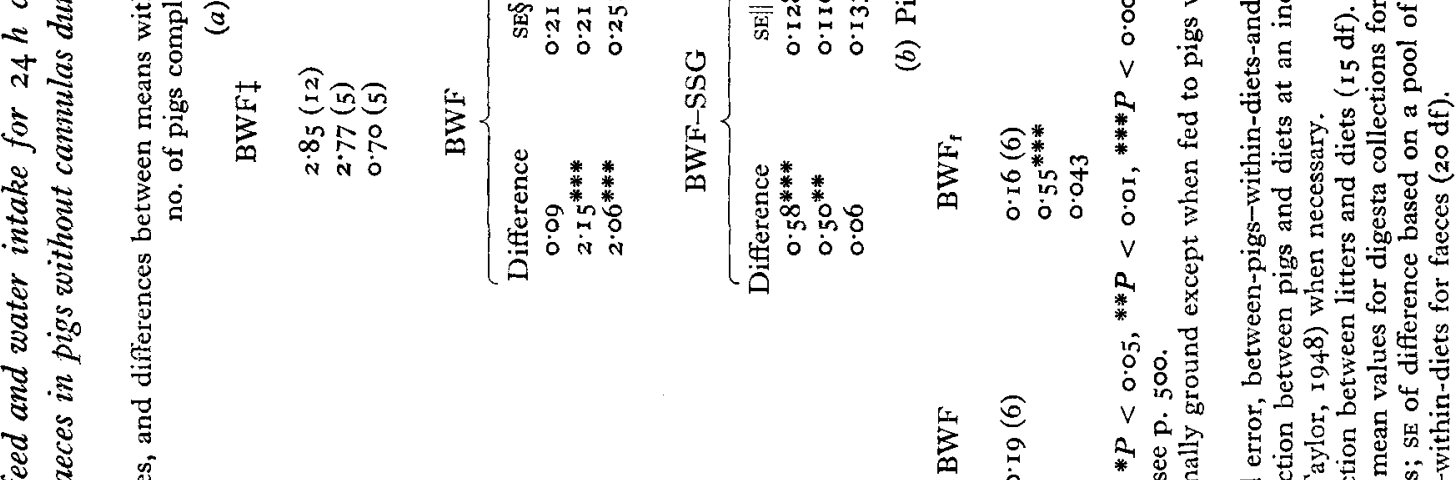

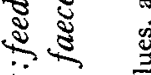

这

कृ

离.

8 \&

i 0

-2
0
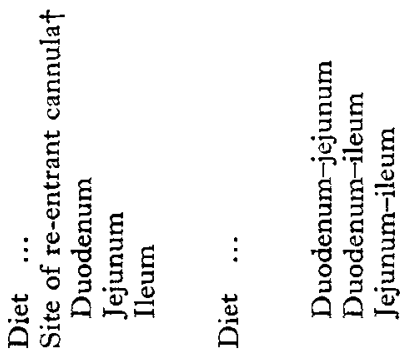
Duodenum

$n 12$

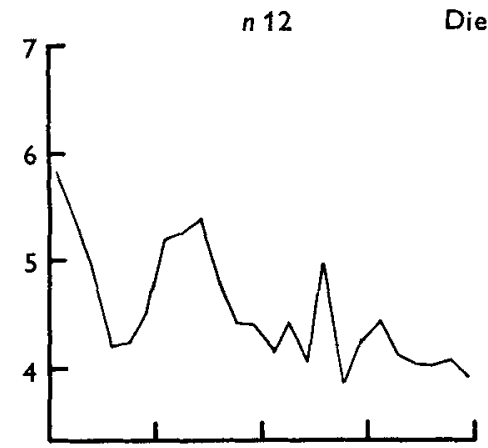

iet BWF
Jejunum

$n 5$

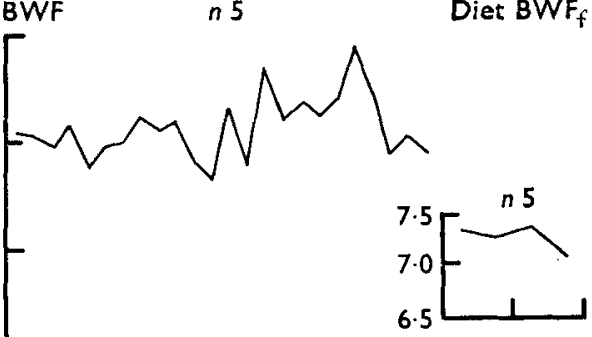

lleum

Diet $B W F_{f}$
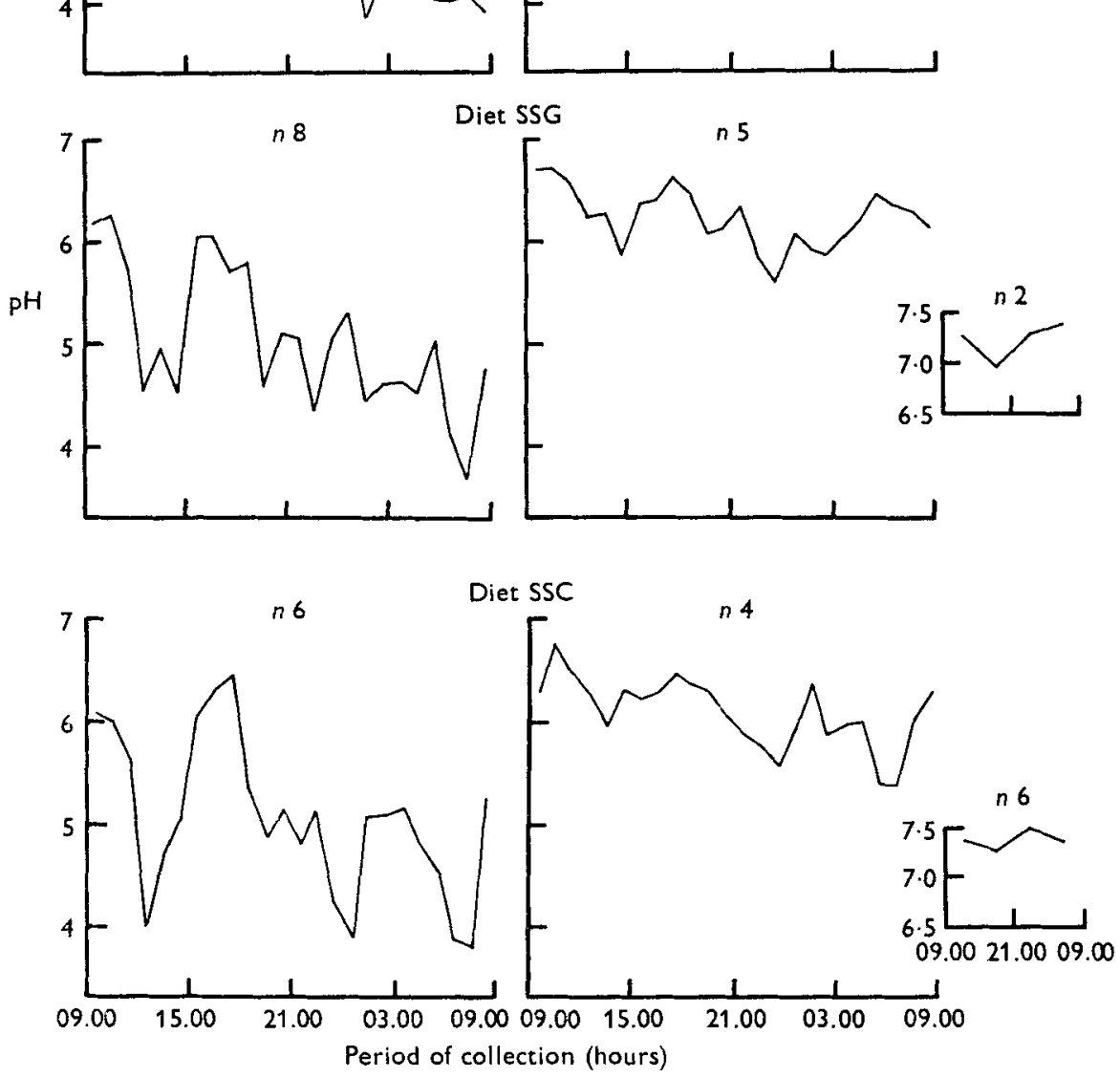

Fig. 3. Mean hourly $\mathrm{pH}$ values $(6 \mathrm{~h}$ value in ileum) in pigs each fitted with a re-entrant cannula at one of three sites (for details, see p. 500) and given successively diets BWF (or $\mathrm{BWF}_{1}$ ), SSG and SSC (for details, see Table r). Pigs were fed at 09.00 and 15.00 hours; $n$ is the no. of pigs completing collections.

there was a wider range of $\mathrm{pH}$ values for diets SSG and SSC than for diet BWF in the duodenum.

The $\mathrm{pH}$ varied over a much smaller range in the jejunum than the duodenum, and varied very little in the ileum. As the distance from the stomach increased so the $\mathrm{pH}$ increased. Postfeeding effects were much less evident in the jejunum than the duodenum, indicating that the digesta were more effectively buffered by intestinal 
Table 3. Determined values for output:feed and water intake for $24 \mathrm{~h}$ collection periods for digesta in the small intestine of pigs cannulated at one of three sites, and for faeces in pigs without cannulas during digestibility trials, when the pigs were given diets $B W F$ $\left(B W F_{\mathrm{i}}\right), S S G$ and $S S C$

(Mean values and standard deviations; no. of pigs completing collections in parentheses)

(a) Cannulated pigs

\begin{tabular}{|c|c|c|c|c|c|c|}
\hline \multirow[t]{2}{*}{ Diet $\ldots$} & \multicolumn{2}{|c|}{ BWF' } & \multicolumn{2}{|c|}{ SSG } & \multicolumn{2}{|r|}{$\mathrm{sSC}$} \\
\hline & Mean & $\operatorname{sD} \ddagger$ & Mean & $\mathrm{sD} \ddagger$ & Mean & \\
\hline \multicolumn{7}{|c|}{ Site of re-entrant cannula* } \\
\hline $\begin{array}{l}\text { Duodenum } \\
\text { Jejunum } \\
\text { Ileum }\end{array}$ & $\begin{array}{l}2 \cdot 85 \\
2 \cdot 76 \\
0 \cdot 69\end{array}$ & $\begin{array}{l}0.450(12) \\
0.306(5) \\
0.136(5)\end{array}$ & $\begin{array}{l}2.25 \\
2.26 \\
0.69\end{array}$ & $\begin{array}{l}0.373(8) \\
0.424(5) \\
0.209(2)\end{array}$ & $\begin{array}{l}2 \cdot 28 \\
1 \cdot 60 \\
0 \cdot 20\end{array}$ & $\begin{array}{l}0.3 \\
0.3\end{array}$ \\
\hline \multicolumn{7}{|c|}{ (b) Pigs without cannulas (six pigs/diet) } \\
\hline Diet .. & & BWF & $\mathrm{BWF}_{1}$ & SSG & & $\mathrm{SSC}$ \\
\hline Faeces & $\begin{array}{l}\text { ean } \\
t\end{array}$ & $\begin{array}{l}0.19 \\
0.010\end{array}$ & $\begin{array}{l}0.16 \\
0.015\end{array}$ & $\begin{array}{l}0.10 \\
0.009\end{array}$ & & $\begin{array}{l}0.02 \\
0.005\end{array}$ \\
\hline
\end{tabular}

* For details of sites, see p. 500 .

+ Diet BWF was normally ground except when fed to pigs with ileal cannulas when it was finelymilled (diet $B W F_{f}$ ); for details of diets, see p. 498 .

$\ddagger$ Based on the variation between pigs for a given diet and site; values are inappropriate for comparisons particularly between diets.

secretions at the former site. The coefficients of variation (\%) between pigs on each diet were, on average, duodenum 23, jejunum (within any $\mathrm{I} h$ period) Io, ileum (within any $6 \mathrm{~h}$ period) 4 .

\section{DISCUSSION}

\section{Digesta flow}

The results of this study confirm the findings of Kvasnitsky (195I), Auffray, Martinet \& Rérat (1967), Noakes, Hill, Freeman \& Annison (1967), Horszczaruk (1971), Zebrowska \& Buraczewska (1972) and Ivan (1974) all of whom found higher flow-rates after feeding than at other times in the duodenum of pigs with re-entrant cannulas, even though the number of animals used by the other authors was often much smaller, and the diet composition and feeding levels varied considerably. Horszczaruk (1971) and Zebrowska \& Buraczewska (1972) also noted that flow continued throughout $24 \mathrm{~h}$ periods.

The flow pattern found in the ileum was similar to that found by Zebrowska $\&$ Buraczewska (1972), who used a diet which was similar to diet SSC and was fed at a similar level, but it was very different to those found by Cunningham, Friend \& Nicholson (1963) who fed low levels of diets containing either cereals, dried skim milk, glucose or lactose to two pigs. The latter authors found that the two pigs used had quite different patterns of digestion and absorption; they also found that the cereal diet passed the ileum $3^{-12} \mathrm{~h}$ after feeding, while most of each of the other diets passed the ileum $0-6 \mathrm{~h}$ after feeding.

The 2-3-fold dilution of the intake by endogenous secretions in $24 \mathrm{~h}$ periods in the anterior small intestine has also been reported by Kvasnitsky ( $195 \mathrm{I}$ ), Horszczaruk 
Table 4. Values for $p H$ for 24 collection periods in the small intestine of pigs cannulated at one of three sites, when the pigs were given diets $B W F\left(B W F_{1}\right), S S G$ and $S S C$

(Mean values, and differences between means with their standard errors for comparisons between sites and diets; no. of pigs completing collections in parentheses)

Diet ...

BWF士

SSG

SSC

Site of re-entrant cannulat

$\begin{array}{ll}\text { Duodenum } & 4 \cdot 42(12) \\ \text { Jejunum } & 5 \cdot 88(5) \\ \text { Ileum } & 7 \cdot 32(5)\end{array}$

$\begin{array}{ll}4 \cdot 86(8) & 4 \cdot 90(6) \\ 6 \cdot 24(5) & 5 \cdot 98(4) \\ 7 \cdot 05(2) & 7 \cdot 33(6)\end{array}$

Comparisons of sites

Diet ...

\begin{tabular}{|c|c|}
\hline \multicolumn{2}{|c|}{ BWF } \\
\hline Difference & SE $\$$ \\
\hline$-1 \cdot 4^{6 * * *}$ & 0.236 \\
\hline$-2.90^{* * *}$ & 0.236 \\
\hline$-1 \cdot 44^{* * * * *}$ & 0.281 \\
\hline
\end{tabular}

$\begin{array}{cc}\text { Difference } & \text { SE } \\ -1 \cdot 39^{* * * *} & 0.253 \\ -2 \cdot 19^{* * *} & 0.351 \\ -0.8 I^{*} & 0.371\end{array}$

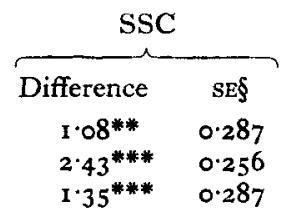

Diet $\quad .$.

$\overbrace{\text { Difference SE }}^{\text {BWF-SSG }}$

Comparisons of diets

$\begin{array}{lllllll}\text { Duodenum-jejunum } & -1 \cdot 4^{* * * *} & 0.236 & -1 \cdot 39^{* * *} & 0.253 & 1 \cdot 08 * * & 0.287 \\ \text { Duodenum-ileum } & -2 \cdot 90^{* * *} & 0.236 & -2 \cdot 19^{* * *} & 0.351 & 2 \cdot 43^{* * *} & 0.256 \\ \text { Jejunum-ileum } & -1 \cdot 44^{* * *} & 0.281 & -0.81 * & 0.371 & 1 \cdot 35^{* * *} & 0.287\end{array}$

$\begin{array}{lccccccr} & \text { Difference } & \text { SE } \| & \text { Difference } & \text { SEN } & \text { Difference } & \text { SE\|l } & \\ \text { Duodenum } & -0.44^{* *} & 0.119 & -0.48^{* *} & 0.132 & 0.04 & 0.169 & 12 \\ \text { Jejunum } & -0.37^{* *} & 0.103 & -0.10 & 0.112 & 0.26 & 0.112 & 7 \\ \text { Ileum } & 0.27 & 0.307 & -0.01 & 0.190 & -0.28 & 0.266 & 5\end{array}$

Levels of significance: ${ }^{*} P<0.05,{ }^{* *} P<0.01, * * * P<0.001$.

$\dagger$ For details of sites, see p. 500 .

$\ddagger$ Diet BWF was normally ground except when fed to pigs with ileal cannulas when it was finelymilled (diet $B W F_{f}$ ); for details of diets, see p. 498 .

$\S$ Based on the pooled error, between-pigs-within-diets-and-sites ( $44 \mathrm{df}$ ).

II Based on the interaction between pigs and diets at an individual site (since there was some evidence of heterogeneity between sites) and an approximation ('Taylor, 1948) when necessary.

Table 5. Determined values for $\mathrm{pH}$ for $24 \mathrm{~h}$ collection periods in the small intestine of pigs cannulated at one of three sites, when the pigs were given diets $B W F\left(B W F_{\mathrm{f}}\right)$, SSG and SSC

(Mean values and standard deviations; no. of pigs completing collections in parentheses)

Diet ...
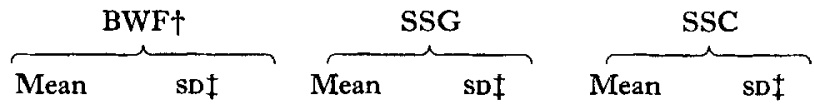

Site of re-entrant cannula*

Duodenum
Jejunum
Ileum

$\begin{array}{llllll}4.42 & 0.365(12) & 4.85 & 0.415(8) & 4.92 & 0.478(6) \\ 5.88 & 0.482(5) & 6.24 & 0.474(5) & 5.92 & 0.376(4) \\ 7.29 & 0.306(5) & 7.14 & 0.113(2) & 7.33 & 0.302(6)\end{array}$

* For details of sites, see p. 5oo.

+ Diet BWF was normally ground except when fed to pigs with ileal cannulas when it was finelymilled (diet $B W F_{t}$ ); for details of diets, see p. 498 .

$\ddagger$ Based on the variation between pigs for a given diet and site; values are inappropriate for comparisons particularly between diets. 
(1971) and Zebrowska \& Buraczewska (1972). While it is impossible to assign the differences in the amount of endogenous secretion to individual factors in the present study, several influences merit attention. The pigs received a mean of about $6 \mathrm{~kg}$ feed and water in $24 \mathrm{~h}$ resulting in $\mathrm{I}^{-1} \mathrm{r} / \mathrm{kg}$ duodenal digesta. Results of work done at this Institute (R. Braude \& I. E. Sambrook, unpublished results) and the results of a single $7 \mathrm{~h}$ collection by Auffray et al. (1967) on bile secretion suggest that the total flow in $24 \mathrm{~h}$ is $2-4 \mathrm{~kg}$ in $40-50 \mathrm{~kg}$ pigs. Pancreatic juice probably contributes $2-4 \mathrm{~kg}$ to duodenal digesta of $40-50 \mathrm{~kg}$ pigs (Tkachev \& Pakhno, I970; Corring, Aumaitre \& Rérat, 1972), so it seems likely that saliva and gastric juice, the total outputs of which have yet to be satisfactorily measured in the pig, contribute 3-7 kg. To be able to account satisfactorily for the endogenous secretions, and the ways in which they vary with the type of diet and level of feeding, requires much more work on the individual contributions.

The amount of endogenous secretion can be influenced by the density (or 'bulk') of a diet. The smaller amount of digesta from diets SSG and SSC than the less dense diet BWF is consistent with the findings of Bakeeva \& Utekhin (1958). The particle size of a diet may also influence gastric secretion: Reimann, Maxwell, Kowalczyk, Benevenga, Grummer \& Hoekstra (1968) found more pepsin (EC $3 \cdot 4.23 .1)$ secretion with finely-ground than coarsely-ground maize diets in pigs, which is inconsistent with the present findings, suggesting that other factors are of importance.

It has been suggested that the method of cannulation used in the duodenum may influence the amount of digesta collected (Laplace \& Tomassone, 1970); these workers obtained nearly $50 \%$ more digesta when using a novel cannulation method, than Auffray et al. (1967). However, the latter authors used a diet similar to diet $\mathrm{SSC}$, and the former authors a diet similar to diet BWF. There was more than $30 \%$ more digesta for diet BWF than for diet SSC in the present study, even though the cannulas were located posterior rather than anterior to the bile duct. Differences similar to those found here between diets in the amounts of digesta in the duodenum have been noted by Zebrowska (1973). Thus the importance of the cannulation method is probably less than Laplace \& Tomassone (1970) supposed, but may need to be considered further.

The very limited evidence available on the pattern of endogenous secretions indicates that peak secretion occurs at the times when digesta flow is high. The flow of dry matter also followed the pattern of flow of digesta, so it is reasonable to suppose that the pattern of flow found in the duodenum in the present study provides an indication of the pattern of gastric emptying even though the cannulas were located posterior to the bile and pancreatic ducts. The results presented here indicate that the mathematical descriptions of the characteristics of gastric emptying studied by using small, soluble, simple test meals in man by Hunt \& Spurrell (195I) or Hopkins (1966) do not appear to apply when high levels of solid feeding are used in growing pigs. Although a sharp decrease in flow was found after the first hour after feeding in the duodenum, which might, if studied over shorter time intervals, indicate some similarity to the test meal situation, there is clearly an 
important difference between emptying of a test meal in $2-3 \mathrm{~h}$ and the continuous emptying during $24 \mathrm{~h}$ found in the present study. The much slower pattern of emptying in the latter instance probably facilitates intestinal homoeostasis and therefore internal homoeostasis.

The composition of a diet is known to influence gastric emptying: increasing the free ion concentration delays the process (Hunt \& Pathak, 1960). The 'free' salt concentrations (i.e. the salts added to the mineral mixtures) were $15.5,37.5$ and $40.2 \mathrm{~g} / \mathrm{kg}$ for diets BWF, SSG and SSC respectively; however, the emptying patterns did not vary greatly. The high level of sucrose in diet SSG might also have delayed emptying (Hunt \& Pathak, 1960). Although it is impossible to isolate independent diet effects on gastric emptying in this study, it is important to be aware of possible influences. The possible influences of gastric $\mathrm{HCl}$ in the duodenum lowering the $\mathrm{pH}$ and inhibiting gastric emptying also merit further attention. The level of feeding is also likely to be a factor influencing gastric emptying, but it has only been studied in detail in young pigs given test meals (Ochia, 1973).

A detailed review of the dynamics of digesta flow in simple-stomached species has been prepared by Laplace (1975).

\section{2. $p H$}

While the $\mathrm{pH}$ of gastric contents of pigs has been measured under various conditions, little attention has been paid to the $\mathrm{pH}$ of duodenal digesta. Kvasnitsky (1951) found a mean $\mathrm{pH}$ of 6.0 in the first half and 6.8 in the second half of the small intestine in a slaughter trial. The same method was used by Clemens, Stevens $\&$ Southworth (1975) who found $\mathrm{pH}$ values of $5.7,6.4$ and 6.8 in the proximal, central and distal thirds of the small intestine. Ivan (1974) studied $\mathrm{pH}$ changes during $\mathrm{I} 2 \mathrm{~h}$ collections from pigs with re-entrant cannulas in the duodenum and found a similar pattern of changes to those in the present study but with mean values $0.25-0.5$ higher. The $\mathrm{pH}$ of ileal digesta of pigs with re-entrant cannulas given molasses was found by $\mathrm{Ly}(197 \mathrm{I})$ to be $7 \cdot 4-7 \cdot 8$. Even though the age of animals, diets and methods used in the studies mentioned were different, there is general agreement about the $\mathrm{pH}$ found in the small intestine.

The role of specific nutrients, level of feeding and physical form of the diet in determining $\mathrm{pH}$ remain largely unknown. It is of interest to note that Lawrence (1970) found that the gastric $\mathrm{pH}$ increased as the particle size of the diet decreased, while Reimann et al. (1968) did not find such an effect. Whether particle size was a factor in determining the significantly lower mean $\mathrm{pH}$ for diet $\mathrm{BWF}$ than the others in the duodenum (see Table 4) remains to be established.

The authors gratefully acknowledge the help of $\mathrm{Dr} \mathrm{H}$. L. Buttle who performed surgical procedures involved in cannulation, of R. J. Pittman, I. E. Sambrook and I. G. Partridge for their help in digesta collection and the maintenance of the animals, and of P. Austen for construction of the digesta 'collection-and-return' system used. 


\section{REF ERENCES}

Ash, R. W. (1962). Anim. Prod. 4, 309.

Auffray, P., Martinet, J. \& Rérat, A. (1967). Annls Biol. anim. Biochim. Biophys. 7, 261.

Bakeeva, E. N. \& Utekhin, B. P. (1958). Sechenov physiol. F. USSR 44, 1077.

Barber, R. S., Braude, R., Mitchell, K. G. \& Pittman, R. J. (1972). Anim. Prod. 14, 199.

Braude, R. \& Mitchell, K. G. (1964). F. Anim. Techns Ass. 15, 71.

Clemens, E. T., Stevens, C. E. \& Southworth, M. (1975). F. Nutr. 105, 759.

Corring, T., Aumaitre, A. \& Rérat, A. (1972). Annls Biol. anim. Biochim. Biophys. 12, 109.

Cunningham, H. M., Friend, D. W. \& Nicholson, J. W. G. (1963). Can. F. Anim. Sci. 43, 215.

Hopkins, A. (1966). F. Physiol., Lond. 182, 144.

Horszczaruk, F. (1971). Biul. Inst. Genet. Hodow. Zwierz. pol. Akad. Nauk 21, 101.

Hunt, J. \& Pathak, J. D. (1960). F. Physiol., Lond. 154, 254.

Hunt, J. N. \& Spurrell, W. B. (1951). Y. Physiol., Lond. 113, 57.

Ivan, M. (1974). A nutritional evaluation of wheat for pigs with particular reference to quality and quantity of protein. PhD Thesis, University of New England, Australia.

Kvasnitsky, A. V. (1951). Voprosy Fisiologii Pishchevarenija u Svinej. Moscow: Sel'Khozgiz (translated by D. E. Kidder).

Laplace, J.-P. (1972). Annls Zootech. 21, 83.

Laplace, J.-P. (1975). Annls Zootech. 24, 489.

Laplace, J.-P. \& Tomassone, R. (1970). Annls Zootech. r9, 303.

Lawrence, T. L. J. (1970). Anim. Prod. 12, I5 I.

Low, A. G. (1974). Observations on the digestion of proteins by the growing pig. PhD Thesis, University of Reading.

Low, A. G. (1976). Proc. Nutr. Soc. 35, 57.

Ly, J. (1971). Revta cub. Cienc. agric. 5, 351.

Markowitz, J., Archibald, J. \& Downie, H. G. (1954). Experimental Surgery, 3rd ed. London: Baillière, Tindall and Cox.

Noakes, D. E., Hill, K. J., Freeman, C. P. \& Annison, E. F. (1967). Proc. Nutr. Soc. 26, vi.

Ochia, B. A. (1973). F. Physiol., Lond. 233, 467.

Reimann, E. M., Maxwell, C. V., Kowalczyk, T., Benevenga, N. J., Grummer, R. H. \& Hoekstra, W. G. (1968). F. Anim. Sci. 27, 992.

Taylor, J. (1948). Nature, Lond. 162, 262.

Tkachev, E. Z. \& Pakhno, V. S. (1970). Sb. nauch. Rab. vses. nauchno-issled. Inst. Zhivotn. $20,25$.

Zebrowska, T. (1973). Roczn. Nauk roln. 95B, 115.

Zebrowska, T. \& Buraczewska, L. (1972). Roczn. Nauk roln. 94B, 81.

\section{EXPLANATION OF PLATE}

A pig with an ileal re-entrant cannula during a collection, standing in a modified Shinfield metabolism cage. For details of cage, see p. 498 and Braude \& Mitchell (I964). 
British Fournal of Nutrition, Vol. 36, No. 3

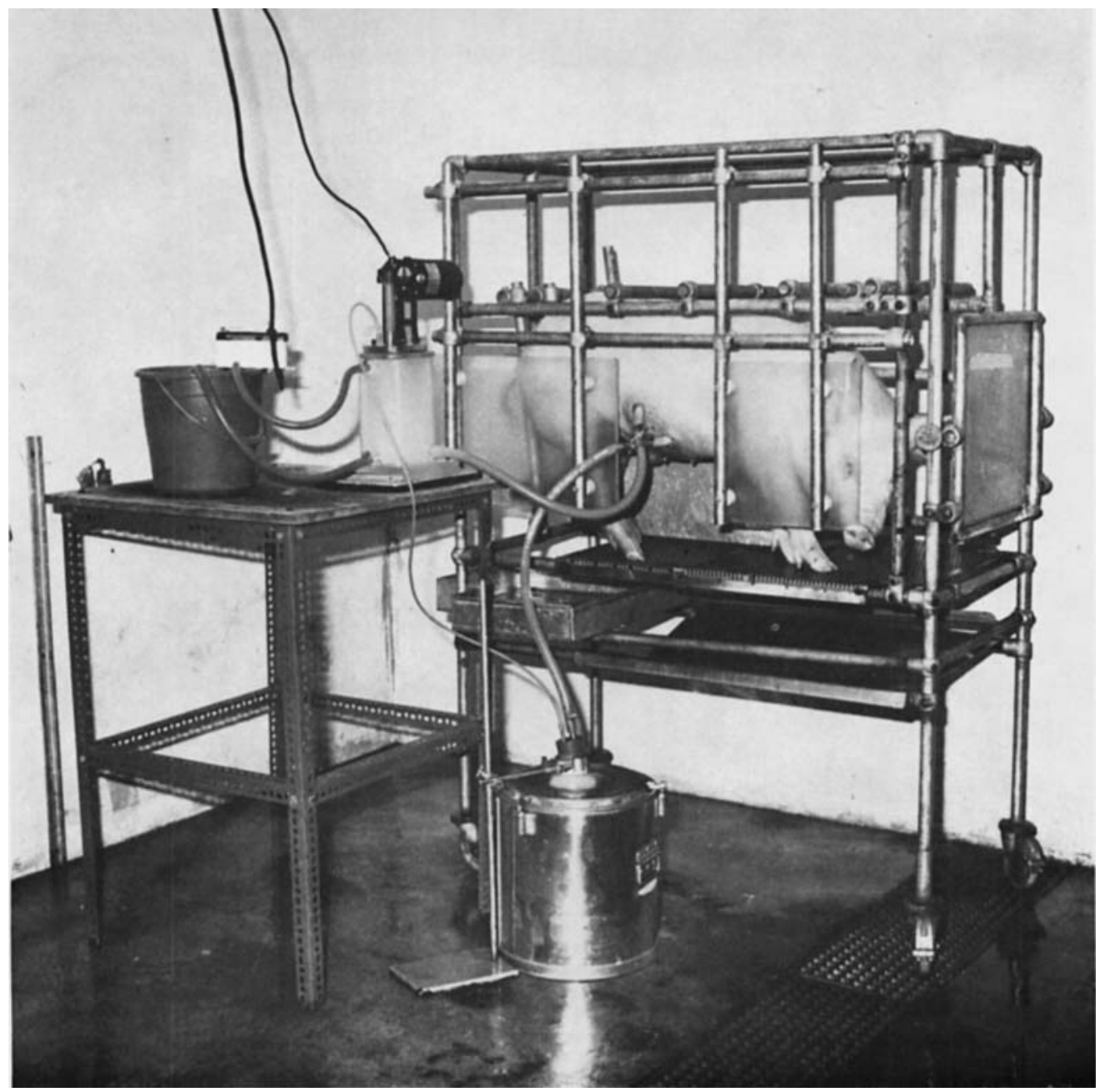

